\title{
Dytiscid Beetle Remains Discovered in a Pellet from a Great Gray Owl, Strix nebulosa, Nest
}

\author{
KEVIN C. R. KERR \\ Department of Integrative Biology, University of Guelph, Guelph, Ontario N1G 2W1 Canada
}

Kerr, Kevin C. R. 2008. Dytiscid beetle remains discovered in a pellet from a Great Gray Owl, Strix nebulosa, nest. Canadian Field-Naturalist 122(1): 78-79.

On 18 July 2007, near Goose Creek, south of Churchill Manitoba, a Great Gray Owl, Strix nebulosa, pellet that contained the pronotum and elytra of a predacious diving beetle, Dytiscus alaskanus, was discovered at a nest.

Key Words: Great Gray Owl, Strix nebulosa, predaceous diving beetle, Dytiscus alaskanus, pellet, Goose Creek, Churchill, Manitoba.

On 18 July 2007, an owl pellet was recovered from the base of an active Great Gray Owl, Strix nebulosa, nest south of Churchill, Manitoba $\left(58^{\circ} 40^{\prime} 28^{\prime \prime} \mathrm{N}\right.$, $\left.94^{\circ} 08^{\prime} 56^{\prime \prime} \mathrm{W}\right)$. The pellet was within the size range reported for this species (Cramp 1985) and contained both the pronotum and elytra from an adult predacious diving beetle (Figure 1). The beetle parts were identified as belonging to Dytiscus alaskanus (Coleoptera: Dytiscidae). This large $(22-30 \mathrm{~mm})$ species is known to be fairly common in the area (Larson et al. 2000; R. E. Roughley, personal communication).

The nest was located on the rafters of a dilapidated cottage adjacent to Goose Creek Road, approximately $5 \mathrm{~km}$ south of Akudlik Village in Churchill. This is at the northern range limit in Manitoba for this species (Lang et al. 1991). Only three pellets were recovered from the nest site. Few pellets fell to ground level due to the structure the nest was sitting on; no additional pellets could be recovered without disturbing the nest. Neither of the other two pellets collected contained any beetle parts. All three pellets were comprised mostly of small rodent remains.

Great Gray Owls feed primarily on voles and the remainder of their diet largely consists of other rodents and small mammals (Bull et al. 1989; Bull and Duncan 1993). Other items tend to include moderatelysized vertebrates (Bull and Duncan 1993). Bull et al. (1989) observed the remains of only five insects after analyzing 1923 pellets from Great Grays nesting in Oregon. Species of insects previously observed in Great Gray Owl pellets have been of questionable origin, as they could have been accidentally ingested with other prey items. The beetle remains discussed here suggest that the insect was actively hunted.

Great Horned Owls have been observed hunting dytiscid beetles in southern Manitoba (Duncan and Lane 1988). Although these owls are commonly regarded as generalist predators, they feed primarily on small mammals (Marti and Kochert 1996). D. alaskanus can reach high population densities in early summer and adults are attracted to lights (Aiken and Wilkinson 1985). These factors, combined with its large size, could make these beetles a viable food source at certain times of the year. Nero (1980) relays anecdotal evidence that a Great Gray Owl once captured a dragonfly beneath a bright light. These findings suggest that Great Gray Owls might opportunistically supplement their diet with non-typical prey items when they are abundant.

\section{Acknowledgments}

I thank Jim Duncan for helpful suggestions on this manuscript, Rob Roughley for identifying the beetle remains, Anaiis Renaud for showing me the nest site, and also my advisor, Paul Hebert, for first bringing the pellet to my attention.

Document Cited (marked $*$ in text)

Bull, E. L., and J. R. Duncan. 1993. Great Gray Owl (Strix nebulosa), The Birds of North America Online. Edited by A. Poole. Ithaca: Cornell Lab of Ornithology; Retrieved from the Birds of North America Online: http://bna.birds. cornell.edu.bnaproxy.birds.cornell.edu/bna/species/041d oi:bna.41 


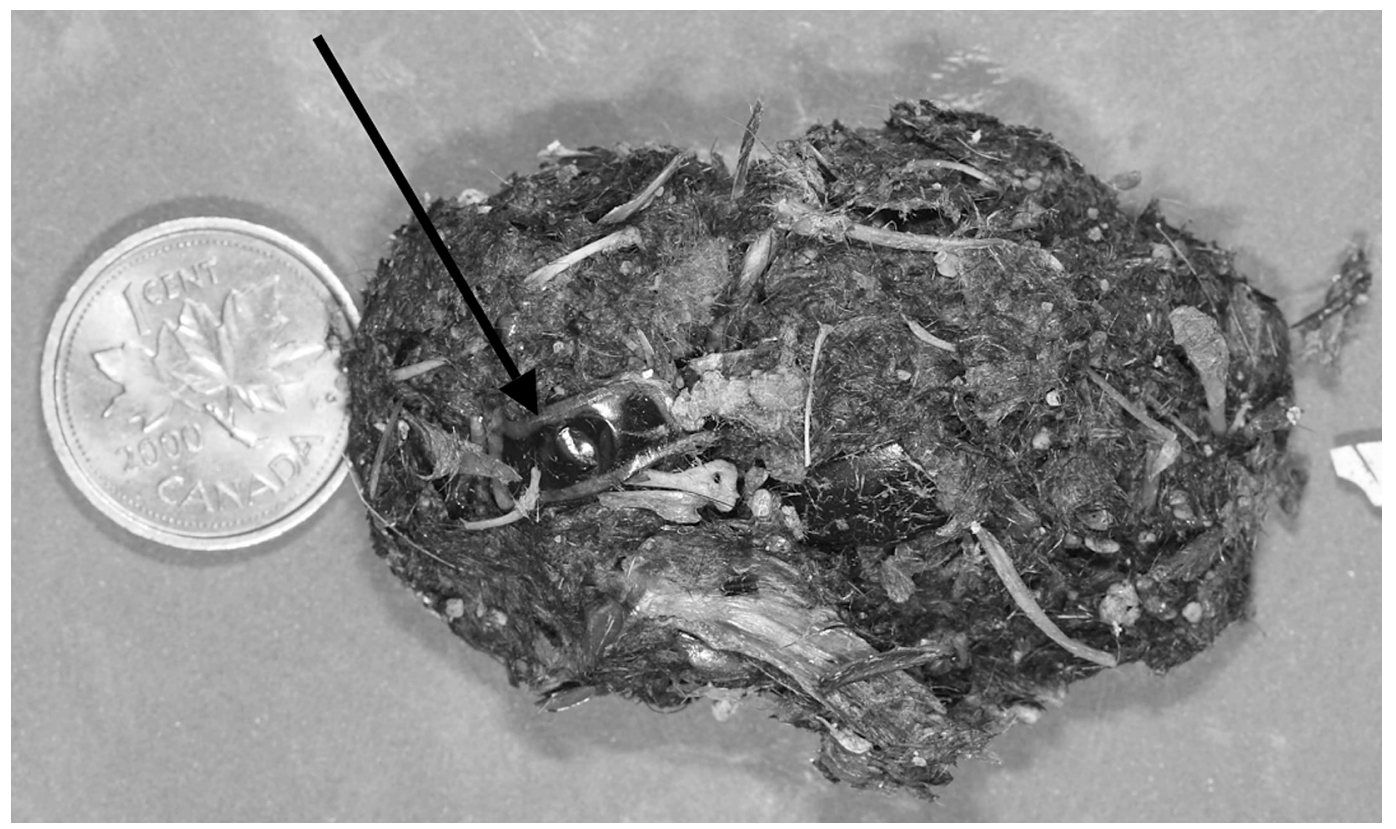

FIGURE 1. Photograph of the owl pellet described in text. The arrow indicates the location of the beetle pronotum. A penny has been included for scale. Photograph by Rick Turner.

\section{Literature Cited}

Aiken, R. B., and C. W. Wilkinson. 1985. Bionomics of Dytiscus alaskanus J. Balfour-Browne (Coleoptera: Dytiscidae) in a Central Alberta Lake. Canadian Journal of Zoology 63: 1316-1323.

Bull, E. L., M. G. Henjum, and R. S. Rohweder. 1989. Diet and optimal foraging of great gray owls. Journal of Wildlife Management 53: 47-50.

Cramp, S. 1985. Handbook of the birds of Europe, the Middle East and North Africa, volume 4. Oxford University Press. 960 pages.

Duncan, J. R., and P. A. Lane. 1988. Great Horned Owl observed "hawking" insects. Journal of Raptor Research 22: 93.
Lang, A. L., J. R. Duncan, S. Ramsay, and J. D. Rising. 1991. Great Gray Owl and Northern Hawk Owl nests at Churchill, Manitoba. Blue Jay 49: 208-214.

Larson, D. J., Y. Alarie, and R. E. Roughley. 2000. Predaceous diving beetles (Coleoptera: Dytiscidae) of the Nearctic region, with emphasis on the fauna of Canada and Alaska. NRC Research Press, Ottawa. 982 pages.

Marti, C. D., and M. N. Kochert. 1996. Diet and trophic characteristics of Great Horned Owls in southwestern Idaho. Journal of Field Ornithology 67: 499-506.

Nero, R. W. 1980. The Great Gray Owl, phantom of the northern forest. Smithsonian Institution, Washington, D.C. 167 pages.

Received 25 February 2008

Accepted 8 August 2008 